\title{
Az Alzheimer-kór molekuláris képi megjelenítése
}

\author{
Albert Annamária oh. ${ }^{1}$ - Borbély Katalin dr. ${ }^{2}$ \\ ${ }^{1}$ Semmelweis Egyetem, Budapest \\ ${ }^{2}$ Országos Onkológiai Intézet, PET/CT Ambulancia, Budapest
}

\begin{abstract}
A társadalom egyre növekvő átlagéletkora az Alzheimer-kór előfordulását jelentősen fokozza. Mindez a társadalmi és gazdasági terhek nagymértékű növekedésével társul, ami sürgős cselekvésre invitál az egészségügy területén is, mind a diagnosztika, mind a terápia részéről. A dementia leggyakoribb oka az Alzheimer-kór, amelynek jellegzetes kórszövettani eltérései jól ismertek. A funkcionális eltérések kimutatása a kórkép korai diagnosztikáját eredményezi, ami évekkel megelőzi a morfológiai eltéréseket. Az anyagcsere-változások kimutatásában, a molekuláris pozitronemissziós tomográfia fontos szerepet játszik. A glükózmetabolikus mintázat az egyes klinikai formáknál jellegzetes mintázati eltéréseket mutat. A $\beta$-amiloid fehérjéhez kötődő számos radiofarmakon közül kiemelendő a kutatásban széles körben alkalmazott $\left[{ }^{11} \mathrm{C}\right]$ Pittsburgh compound $\mathrm{B}$, valamint a diagnosztikában széleskörúen elfogadott $\left[{ }^{18} \mathrm{~F}\right]$ florbetapir. A közelmúltban jelentek meg a tau fehérje alkotta neurofibrillaris kötegeket megjelenítő trészerek, és azóta is folyamatosan fejlődó, újabb radiofarmakonok jelennek meg. Ezek a trészerek fontos szerepet játszanak a kutatásban és a diagnosztikában egyaránt.
\end{abstract}

Orv Hetil. 2019; 160(33): 1289-1295.

Kulcsszavak: Alzheimer-kór, pozitronemissziós tomográfia, fluoro-dezoxi-glükóz, amiloid-, tauképalkotás

\section{Molecular imaging of Alzheimer's disease}

The ever-growing average age of the society significantly increases the occurrence of Alzheimer's disease. The increased prevalence represents considerable social and economic burden, which urges the development of diagnostic and therapeutic methods in the field. The most common cause of dementia is Alzheimer's disease, the typical histopathological abnormality of which are well known. The detection of functional changes results in the early diagnosis of the disease, which precedes the morphological changes by years. Positron-emission tomography plays an important role in the demonstration of metabolic changes. The glucose metabolic pattern differs significantly in each clinical form of dementia. The most important $\beta$-amyloid-binding radiopharmaceuticals that should be highlighted are $\left[{ }^{11} \mathrm{C}\right]$ Pittsburgh compound $\mathrm{B}$ that is widely used in the research and $\left[{ }^{18} \mathrm{~F}\right]$ florbetapir that is commonly approved in diagnostics. Tracers visualising neurofibrillary tangles consisting of tau protein appeared most recently. The development continues; newer and newer radiopharmaceuticals appear. These tracers play an important role in both the research and the diagnostics.

Keywords: Alzheimer's disease, positron emission tomography, fluorodeoxyglucose, amyloid, tau imaging

Albert A, Borbély K. [Molecular imaging of Alzheimer's disease]. Orv Hetil. 2019; 160(33): 1289-1295.

(Beérkezett: 2019. március 19.; elfogadva: 2019. április 9.

\section{A Szerkesztőség felkérésére készített tanulmány.}

\section{Rövidítések}

${ }^{11} \mathrm{C}=$ szén-11 (PET-izotóp); ${ }^{15} \mathrm{O}=$ oxigén-15 (PET-izotóp); ${ }^{18} \mathrm{~F}=$ fluor-18 (PET-izotópok); $\mathrm{AD}=$ (Alzheimer's disease $) \mathrm{Alz}$ heimer-kór; CSF = cerebrospinalis folyadék, liquor, agyvíz; CT $=($ computed tomography $)$ számítógépes tomográfa $; \mathrm{EOAD}=$ (early-onset Alzheimer's disease) korai kezdetű Alzheimer-kór; FDA = (Food and Drug Administration) az Amerikai Egyesült Államok Élelmiszer- és Gyógyszerfelügyelete; FDG = fluoro- dezoxi-glükóz; LOAD = (late-onset Alzheimer's disease $)$ késői kezdetú Alzheimer-kór; MCI = (mild cognitive impairment) enyhe kognitív hanyatlás; MRI = (magnetic resonance imaging $)$ mágnesesrezonancia-képalkotás; PET = (positron emission tomography) pozitronemissziós tomográfia; $\mathrm{PiB}=$ Pittsburgh compound B; USA $=($ United States of America) Amerikai Egyesült Államok 
Az életkörülmények javulása, az orvosi technika, a közegészségügy fejlődése a lakosság átlagéletkorának világszerte észlelhető jelentős növekedését eredményezte. Az idős populáció növekedésével azonban a dementia előfordulásának gyakorisága is drámaian emelkedett, ami hatalmas gazdasági és társadalmi teherrel társul. A kórkép korai pontos felismerése elengedhetetlen a megfelelő terápia megkezdéséhez, ami jelentősen befolyásolja a betegség kimenetelét [1,2]. A dementia a különböző kognitív funkciók zavarával járó betegség. Az Amerikai Pszichiátriai Társaság által kiadott legújabb kritériumrendszer, a Diagnostic and Statistical Manual of Mental Disorders 5. kiadása (DSM-5) alapján a dementia olyan jelentős neurokognitív betegség, amely mind a kognitív funkciókban, mind a mindennapi élet tevékenységeiben zavart okoz $[1,3]$. A 65 év feletti betegek esetében a kognitív hanyatlás hátterében a leggyakrabban neurodegeneratív eredet áll, és ezen belül a leggyakoribb az Alzheimer-kór (Alzheimer's disease, $\mathrm{AD}$ ). A megbetegedés tüneteit először Alois Alzheimer írta le 1907-ben. Az AD-t hisztopatológiailag idegsejtpusztulás, granulovacuolás degeneráció, tau fehérjékből álló neurofibrillaris kötegek és $\beta$-amiloid fehérje alkotta szenilis plakkok jellemzik $[1,3]$.

\section{Az Alzheimer-kór képalkotó diagnosztikája}

\section{Strukturális képalkotás}

A mágnesesrezonancia-képalkotás (magnetic resonance imaging, MRI) kitúnő lágyszöveti felbontással bír, és funkcionális szekvenciákat is alkalmaz. A megbízható lokalizálás, a módszer növekvő funkcionális lehetőségei háttérbe szorították a komputertomográfia (computed tomography, CT) alkalmazását dementiában $[3,4]$. Az AD-t illetően, tanulmányokkal igazolták, hogy a halántéklebeny medialis részén kimutatható atrófia súlyossága 80-85\%-os szenzitivitással és specificitással bír a betegség diagnosztikájában, és kapcsolatban áll mind a kognitív hanyatlással, mind a neurofibrillaris kötegek jelenlétével [3]. A különböző diagnosztikai módszerek kombinálásával előre jelezhető a dementia kialakulásának lehetősége. Enyhe kognitív hanyatlás (mild cognitive impairment, MCI) tüneteivel, azokban az egyénekben, akiknél a temporalis lebeny medialis részén nagyobb mértékü sorvadást tapasztaltak, valamint a cerebrospinalis folyadékban (CSF) alacsonyabb $\beta$-amiloid- és magasabb taufehérjeszintet mértek, 94\%-os valószínúséggel alakultak ki a dementia tünetei [5]. Az MR-vizsgálat során kapott eltérések önmagukban nem elegendőek a diagnózis felállításához, de a CSF-minták és a funkcionális képalkotó vizsgálatok eredményei segítséget nyújthatnak [3].

\section{Funkcionális képalkotás, nukleáris medicina}

A nukleáris medicina az élő sejtek múködésének és életfolyamatainak képi megjelenítésével foglalkozik [3]. Fontos megjegyezni, hogy az idegsejtekben létrejött anyagcsere-változások korábban és érzékenyebben kimutathatók a funkcionális képalkotó eljárásokkal, mint ahogy az MR-vizsgálat eredményei alapján várnánk [6]. A pozitronemissziós tomográfia (PET) során pozitront kibocsátó izotóppal jelzett specifikus molekulát juttatnak a szervezetbe, és in vivo mérhető és számszerúsíthető a radiofarmakon eloszlása. A módszer segítségével a különböző biokémiai, farmakokinetikai, -dinámiai folyamatok sebessége vizsgálható és lokalizálható a szervezetben. A számos, pozitront emittáló izotóp közül a leggyakrabban a fluor-18 $\left({ }^{18} \mathrm{~F}\right)$-, az oxigén- $15\left({ }^{15} \mathrm{O}\right)$ - és a szén-11 $\left({ }^{11} \mathrm{C}\right)$-izotópot használják. A jelzómolekula típusát a vizsgálni kívánt folyamat, valamint a szerv funkciója határozza meg $[1,3,7]$.

A funkcionális és strukturális képalkotó technikák egymásba illesztésével olyan multimodális hibrid rendszerek (PET/CT, PET/MR stb.) születtek, amelyek egyszerre nyújtanak morfológiai és múködésbeli információt a szervezetről. 2001-ben a PET/CT bevezetése lehetővé tette a dementia funkcionális megközelítését, ami neuropszichológiai tesztekkel alkalmazva különösen hasznosnak bizonyul. Hazánkban 2005-tôl a PET-módszert csak PET/CT berendezések formájában használják. A PET/MR 2011-ben történő bevezetése lehetôvé tette a betegek sugárterhelésének számottevő csökkentését, ami a gyerekek, fiatal felnőttek és a krónikus betegségek követése során elengedhetetlen. 2014-tól Magyarországon is elérhető a PET/MR [7-9].

\section{A glükózanyagcsere feltérképezése}

A (F-18)-2-fluoro-2-dezoxi-D-glükóz (FDG) vegyületet Phelps és mtsai alkalmazták az emberi agy cukoranyagcseréjének vizsgálatában. Az FDG-PET jó térbeli felbontással és nagy szenzitivitással bíró, nem invazív módszer az agyi metabolizmus mérésében és feltérképezésében. A ${ }^{18} \mathrm{~F}$-izotóp hosszú felezési ideje segítette a klinikai gyakorlatban történő széles körú elterjedését [10]. Az FDG-PET a cukorfelhasználás csökkenésének mintázatával jelzi azokat a helyeket, ahol az idegsejtek és a közöttük lévő szinaptikus kapcsolatok aktivitása csökkent vagy megszúnt [11].

AD-ban jellemzően a parietotemporalis asszociációs kéregben, a hátsó cingularis és praecuneus régiókban mérhető az FDG csökkent felvétele [12]. A hátsó cingularis kéregben detektálható csökkent FDG-felvétel a frontotemporalis dementiában érintett személyek 27$42 \%$-ában is jelen volt, aminek alapján ez a mintázat nem mondható AD-specifikusnak [13]. Az anyagcsere-vizsgálat hasznos az MCI tüneteit mutató egyének esetében, akiknél később manifesztálódik a kór. Az egyik vizsgálat során az $\mathrm{AD}$-ra jellemző temporoparietalis anyagcserecsökkenés mintázatát hasonlították össze AD-ban szenvedő betegekben, egészségesekben és MCI tüneteit mutató egyénekben, akiknél később jelentkeztek vagy nem jelentkeztek a dementia tünetei. A metabolikus aktivitás változása szignifikánsan kifejezettebb volt azon egyének- 
ben, akiknél később kialakult a betegség, a csökkenés mértéke azonban nem függött össze a dementiába történő progresszió idejével, de korrelált a kórkép súlyosságával, a Mini Mentál Teszt eredményeivel [11].

A frontalis lebeny érintettsége a betegség késői stádiumára jellemző, viszont egészséges idős egyének esetében is megfigyelheto", ezért fontos a „fiziológiás öregedés” agyi mintázatának ismerete $[9,12]$.

Az AD különböző klinikai típusainál eltérő anyagcsere-mintázat figyelhető meg. A korai kezdetű $\mathrm{AD}$ (earlyonset Alzheimer's disease, EOAD) esetében a bal praecuneus területén mérhető kifejezett glükózanyagcserecsökkenés. Ez az elváltozás nagyobb mértékű, kiterjedtebb és gyorsabban progrediáló folyamattal társul, mint a jobb cingularis kérget érintő késői típusú $\mathrm{AD}$ (late-onset Alzheimer's disease, LOAD) [14, 15]. Az EOADban érintett betegeknél tapasztalták, hogy a kifejezett metabolikus változást mutató területekben hiányzik a specifikus $\beta$-amiloid-patológia. Ez arra utal, hogy ezen klinikai megjelenés hátterében nagyobbrészt anyagcsereváltozások állnak, és nem a kóros fehérjelerakódás [15].

$\mathrm{Az}$ EOAD típusos és atípusos megjelenésú formái is különböző metabolikus mintázattal jellemezhetők. Típusos esetben szignifikáns anyagcsere-csökkenés a paralimbicus régiót érinti, atípusos formában azonban diffúz hipometabolizmus jellemző az asszociatív kérgi területekben, a hátsó régiókban [15].

Ezeken túlmenően, az EOAD minden klinikai variánsa esetén más régió anyagcsere-csökkenése figyelhető meg. Azon személyekben, akiknél a nyelvi készségek funkciózavara az elsődleges, a domináns félteke Wernicke- és Broca-mezője, valamint a thalamus érintettsége jellemző. A vizuális funkciózavarral küzdő betegeknél a jobb félteke elsődleges és magasabb rendű látóközpontjában tapasztaltak eltérést. A végrehajtó funkciók zavarában megnyilvánuló formában a praefontalis cortex hipometabolizmusát találták, ez az elváltozás azonban nem volt szignifikáns a típusos megjelenésú formában tapasztalt anyagcsere-változásokhoz képest. Az ezeken a specifikus területeken tapasztalt metabolikus elváltozások jól korrelálnak a klinikai tünetekkel, az anyagcsere-csökkenés mértéke és a neuropszichológiai tesztek pontszáma között egyenes arányosság áll fenn [15].

\section{Amiloid-képalkotás}

Az AD-ra jellemző két kórszövettani elváltozás egyike a $\beta$-amiloid fehérjéből álló szenilis plakkok jelenléte. A fehérje az amiloid prekurzor proteinből képződik enzim által katalizált folyamatok révén. A felhalmozódás $\mathrm{AD}$ ban betöltött szerepét először John Hardy és David Allsop fogalmazta meg [16, 17]. Az amiloidfelrakódások gyulladást előidézve károsítják a sejtek fehérjéit, más makromolekulák szerkezetét, gátolják a neuronok közötti jelátvitelt, amelyek a sejt pusztulásához vezetnek $[18,19]$. Az AD-ra jellemző szenilis plakkok a kóros $\beta$-amiloid fehérjék mellett kóros szerkezetű dendriteket, axonokat, aktivált microgliát és reaktív astrocytát is tartalmaznak. Úgynevezett diffúz felrakódás esetén a fehérje mellett nincsenek jelen a fent említett kóros struktúrák és az aktivált sejtek. A patológiai elváltozások ezen két szélsőséges megjelenési formája között az átmenet folyamatos. Fontos megjegyezni, hogy egészséges idős egyének esetében a diffúz felrakódás mellett néhány plakk a betegség hiányában is előfordulhat [18]. Megfelelő trészert alkalmazva, PET-technikával a fehérjefelrakódások megjeleníthetők és mérhetők [3].

A ${ }^{11} \mathrm{C}$-izotóppal jelzett Pittsburgh compound B $\left(\left[{ }^{11} \mathrm{C}\right]\right.$ $\mathrm{PiB})$ a szövettani vizsgálatok során használt, amiloid fehérjét kötő festék szerkezeti módosításával jött létre. A vegyület gyorsan átjut a vér-agy gáton, specifikusan és reverzibilisen képes kötődni a lerakódott fehérjékhez. A szürkeállományból gyorsan kimosódik, míg a fehérállományban lassabban megy végbe ez a folyamat. Az első humánvizsgálatok alkalmával egészséges és $\mathrm{AD}$-ban szenvedő betegek adatait hasonlították össze. A betegcsoportban jelentős radiofarmakon-kötődést tapasztaltak a frontalis, parietalis és temporalis lebenyekben és a striatumban. Az agy többi régiójában nem volt különbség a trészer felvételi és kiürülési kinetikájában a két csoport között. Az anyagcsere-változással együtt értékelve,

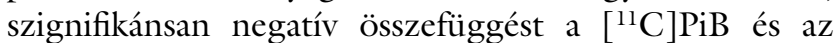
FDG felvétele között csak a parietalis lebenyben tapasztaltak [20]. Egészséges és dementiával élő személyek PET-eredményeit összehasonlítva megállapították, hogy a $\left[{ }^{11} \mathrm{C}\right] \mathrm{PiB}$ diagnosztikai pontossága nagy a kórfolyamat igazolásában $[20,21]$. A [ $\left.{ }^{11} \mathrm{C}\right] \mathrm{PiB}$ agykérgi kötődése jól korrelál a CSF-amiloid-csökkenéssel, a szövettani vizsgálat eredményeivel és az MR-en látható agysorvadás mértékével [22-24]. A nagyobb mértékü radiofarmakon-felvétel alacsonyabb Mini Mentál Teszt-eredménnyel társult, viszont a két eredmény között nem találtak szignifikáns különbséget [20]. A ${ }^{11} \mathrm{C}$-izotóp rövid, 20 perces

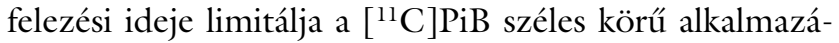
sát, csak ciklotron közelében végezhető a vizsgálat. Kutatási célokra és mint első szelektív amiloidkötő radiofarmakon referenciaként szolgál a kifejlesztés alatt álló trészerek vizsgálatához [24, 25].

Napjainkra számos, ${ }^{18} \mathrm{~F}$-izotóppal (110 perces felezési idő) jelölt radiofarmakont fejlesztettek ki $[22,26]$. Ezek egyike a széles körben alkalmazott florbetapir, amely nagy affinitással és specificitással kötődik a $\beta$-amiloid fehérjéhez. Kedvező felvételi és kimosódási kinetikával és gyors metabolizmussal rendelkezik. A boncolási vizsgálatok során a $\left[{ }^{18} \mathrm{~F}\right]$ florbetapir-PET szenzitivitását 93\%-osnak, fajlagosságát 100\%-osnak véleményezték [26]. A $\left[{ }^{11} \mathrm{C}\right] \mathrm{PiB}$-vegyülettel összehasonlítva igazolták, hogy jól kötődik a kóros szerkezetű amiloid fehérjéhez. Fontos megjegyezni, hogy a florbetapirra (más ${ }^{18} \mathrm{~F}$-izotóppal jelzett radioligandhoz hasonlóan) magasabb nem specifikus fehérállományi kötődés jellemző, ami nehezíti a képek vizuális értékelését $[24,27]$. A trészert széleskörűen alkalmazzák a kutatás területén, többek között AD-ra kifejlesztett kísérleti gyógyszerek hatásának vizsgálatá- 
ban [26]. A florbetapir radiofarmakont 2012-ben az amerikai egyesült államokbeli (United States of America, USA) Élelmiszer- és Gyógyszerfelügyelet (Food and Drug Administration, FDA) befogadta [28].

Számos trészert kifejlesztettek az amiloid fehérje jelzésére, mint a [ $\left.{ }^{11} \mathrm{C}\right] \mathrm{BF}-227$, melynek széles körü felhasználását korlátozza az izotóp rövid felezési ideje [22, 29]. E radioligandot továbbfejlesztve jelent meg a ${ }^{18} \mathrm{~F}$-ral jelzett $\left[{ }^{18} \mathrm{~F}\right] \mathrm{FACT}[30]$. A florbetapir mellett még két másik radiofarmakon, a flutemetamol, illetve a florbetaben is befogadást nyert az USA-ban az FDA által [28]. A $\left[{ }^{18} \mathrm{~F}\right]$ NAV4694 radioligand az eddigi vizsgálatok alapján alacsony nem specifikus fehérállományi kötődést mutat, ami előnyösebbé teheti a fenti radioligandokkal szemben. A radiofarmakon kettes és hármas fázisú vizsgálata jelenleg folyamatban van $[24,28]$. Higashi és mtsai a közelmúltban fejlesztették ki a még szintén vizsgálat alatt lévő $\left[{ }^{18} \mathrm{~F}\right] \mathrm{FPYBF}-2$ trészert [31].

A $\beta$-amiloid fehérjék alkotta plakkok, illetve azok mennyisége, elhelyezkedése, valamint a klinikai tünetek súlyossága és a betegség fennállásának időtartama között nem találtak összefüggést. A kóros tau fehérjék alkotta neurofibrillaris kötegek jelenléte azonban jó korrelációt mutat a tünetek súlyosságával, valamint a betegség progressziójával [32].

\section{Tauképalkotás}

Az AD-ra jellemző másik szövettani elváltozás a túlfoszforilált tau fehérjékből álló neurofibrillaris kötegek. A tau a microtubulus-asszociált fehérjék csoportjába tartozik, szerepet játszik a microtubulus szerkezetének stabilizálásában, dinamikus változásának szabályozásában, és részt vehet az axonalis transzportfolyamatok irányításában is. Állatkísérletekben bizonyították, hogy a tau fehérje a neuronaktivitás kontrolljában, illetve az idegsejtképződésben is részt vesz. A fehérje natív állapotban antiaggregatív szerkezetü, a nagymértékű foszforilálódás során szerkezete megváltozik, hajlamossá teszi a neurofibrillaris kötegek kialakulására. A kóros fehérje terjedése az agyban a Braak-stádiumokat követi. Az I-II. stádiumban a transentorhinalis és entorhinalis régiókban, a III-IV. stádiumban a hippocampusban, majd ezt követően az V. fázisban az agykéreg minden területén fellelhetők az intracellularis neurofibrillaris kötegek. A folyamat feltételezhetően a sejtek közötti szinaptikus útvonalat igénybe véve terjed. AD esetében a kognitív funkcióban bekövetkező hanyatlás fokozatossága összhangban van a neurofibrillaris kötegek lépcsőzetes megjelenésével. A neurofibrillaris kötegek okozta idegsejt-károsodás patomechanizmusának feltárása az utóbbi időszakban nagy fejlődésnek indult, a pontos folyamat azonban továbbra sem teljesen tisztázott [33].

A közelmúltban elérhetővé váltak a tau fehérje leképezését szolgáló, első generációs PET-radiofarmakonok. A $\left[{ }^{18} \mathrm{~F}\right]$ flortaucipir, korábbi nevén $\left[{ }^{18} \mathrm{~F}\right] \mathrm{AV}-1451$, nagy affinitással és szelektíven kötődik a neurofibrillaris köte- gekhez, és nem mutat kötődést a $\beta$-amiloid fehérjéhez [32]. A trészert kedvező lipofilitás, metabolikus stabilitás, gyors agyi felvétel és kimosódás jellemzi, és az amiloidkötő radiofarmakonokkal szemben nincs nem specifikus fehérállományi retenciója [32, 34, 35]. Hátránya, hogy számos, a központi idegrendszerben előforduló transzmembrán csatornához, transzporterhez és receptorhoz kötődhet, befolyásolva azok múködését. Ezért humán felhasználásban a legnagyobb megengedett trészerdózis $13 \mu \mathrm{g}$. AD-ban szenvedő és egészséges egyének vizsgálata során az entorhinalis és parahippocampalis régiókban szignifikánsan magasabb radiofarmakon-kötődést észleltek a betegcsoportban a kontrollhoz viszonyítva [34]. A dementia által érintett egyénekben, valamint MCI-tünetekkel, kifejezetten az alsó és oldalsó temporoparietalis, a parietooccipitalis és a hátsó cingularis régióban észlelték a trészer felhalmozódását. Az alsó temporalis retenció mértéke összefüggést mutatott a Mini Mentál Teszttel mért kognitív hanyatlás mértékével, valamint a $\left.{ }^{11} \mathrm{C}\right] \mathrm{PiB}$ magasabb átlagos agykérgi kötődésével [35]. A taulerakódás és az anyagcsere-változás között szoros összefüggés mutatkozott [36]. Whitwell és mtsai a $\left[{ }^{18} \mathrm{~F}\right]$ flortaucipir, FDG-PET, PiB-PET és MR eredményeinek összehasonlító tanulmányában a legszorosabb összefüggést a tau-PET és a cukoranyagcsere között találták, a leggyengébb pedig az amiloid-PET és az MR között volt. Ebből is következik, hogy a taufehérjelerakódás, valamint a metabolikus változások megelőzik a strukturális elváltozásokat. Az MR-felvételeken látható agysorvadás a betegség egy késői stádiumára utal [37]. A $\left[{ }^{18} \mathrm{~F}\right]$ flortaucipir-PET igen nagy diagnosztikai pontossággal elkülöníti a beteg egyéneket az egészségesektől. Ugyancsak hasonlóan eredményesnek bizonyult az AD korai diagnosztikájában, amikor az agykéregben még nem észlelhető a neurofibrillaris kötegek elterjedése, mint a CSF-ben mért tau mennyiségének eltérése. Az előzőekből következtették, hogy megbízható nem invazív alternatíva kerül kilátásba az $\mathrm{AD}$ diagnosztikájában [38]. Más munkacsoportok is igazolták, hogy a $\left[{ }^{18} \mathrm{~F}\right]$ flortaucipir-PET megfelelőnek bizonyul a betegek elkülönítésében az egészségesektől, valamint jelentős klinikai értékkel bír a betegség progressziójának nyomon követésében és a betegségmódosító kezelések hatékonyságának mérésében [35].

Számtalan más radiofarmakont is kifejlesztettek, amelyek nagy affinitással kötődnek a tau fehérjéhez. Idetartoznak a THK-molekulacsalád tagjai, mint a $\left[{ }^{18} \mathrm{~F}\right] \mathrm{THK}-$ 523, $\left[{ }^{18} \mathrm{~F}\right]$ THK-5105, $\left[{ }^{18} \mathrm{~F}\right]$ THK-5117, $\left[{ }^{18} \mathrm{~F}\right]$ THK-5317 és a $\left[{ }^{18} \mathrm{~F}\right]$ THK-5351 [39-43]. A $\left[{ }^{11} \mathrm{C}\right] \mathrm{PBB3}$ a szabad koncentrációjától függően, szelektíven kötődik a tau fehérjéhez, nagyobb mennyiségben képes kötődni a $\beta$-amiloid-felrakódásokhoz is [44]. Alacsonyabb nem specifikus fehérállományi kötődéssel rendelkezik, mint a $\left[{ }^{11} \mathrm{C}\right] \mathrm{PiB}$, az agyhártyák vénás sinusaiban azonban felhalmozódást mutat [44]. Jelenleg is vizsgálatok folynak a $\left[{ }^{18} \mathrm{~F}\right] \mathrm{MK}-6240$ radiofarmakonnal, amely az eddigi eredmények alapján megfelelő érzékenységgel képes detek- 
tálni a tau fehérjék felhalmozódását, ami hozzájárulhat a kórfolyamat korai stádiumban történő kimutatásához [45].

A ${ }^{11}$ C-izotóppal való jelölésben rejlő előnyök és lehetőségek a gyógyszerkutatás egynapos, gyors vizsgálatai során is megmutatkoznak. A gyors felezési idő lehetővé teszi a 2-3 óránkénti ismételt vizsgálatot, a kutatásban részt vevő személyt nem szükséges többször visszahívni, és a gyógyszerhatás megbízhatóan nyomon követhetó [46].

\section{Megbeszélés}

Az átlagéletkor növekedésével a dementia előfordulása is növekszik, komoly terhet róva a társadalomra. Fontos a korai és pontos diagnózis a hatékony kezelés mielőbbi megkezdéséhez. Jelenleg a világban kb. 47 millió egyént érint a betegség, és 2050-re várhatóan 131 milliónál is nagyobb lehet a betegek száma [2]. A leggyakoribb dementiatípus az AD, igen jellegzetes szövettani elváltozásokkal, mint a $\beta$-amiloid fehérje alkotta extracellularis szenilis plakkok és a tau fehérjéból felépülő neurofibrillaris kötegek [18]. A diagnózis felállítását számos módszer segíti, az invazív lumbálpunkciótól a különböző neuropszichológiai teszteken át a különböző képalkotó vizsgálatokig, külön-külön azonban ezek egyike sem rendelkezik megfelelő diagnosztikus pontossággal. A módszerek kombinálása lehetôséget nyújt a diagnózis pontosítására $[3,5]$. A strukturális képalkotó eljárások nem rendelkeznek megfelelő érzékenységgel, és jól ismert, hogy a morfológiai eltérések hátterében már régebb óta zajló funkcionális elváltozás áll [37]. Ez a felismerés, valamint a folyamatos fejlődést mutató trészerek nyújtotta széles körű lehetôségek a PET-módszert az agymúködés nem invazív vizsgálatának arany etalonjává tette [6]. A morfológiai és múködésbeli információkat együtt szolgáltató multimodális hibrid technikák nagy segítséget nyújtanak a funkcionális elváltozások anatómiai lokalizálásában. A régebb óta használt FDG-PET segítséget nyújt az anyagcsere-változás kimutatásában, az agyi érintettség lokalizálásában. A hátsó cingularis régió hipometabolizmusa és a betegség klinikai megjelenése, a beteg életkora és a panaszok életkori kezdete között szignifikáns összefüggést találtak. Ez a metabolikus minta nem specifikus ADra, mivel a frontotemporalis dementiában szenvedő betegek jelentős hányadában szintén látható hasonló mintázat [13]. A jelzőmolekulák fejlődésével lehetőség adódott egyes fehérjék jelenlétének kimutatására [3]. Az amiloidkötő radiofarmakonok specifikus fehérjekötő képességük révén képesek lokalizálni a kóros plakkokat a központi idegrendszerben [20]. A jelöléshez számos trészer áll rendelkezésre, a cikk ezeknek csupán a töredékét tárgyalja. A kóros fehérjefelhalmozódás leképezése nem specifikus AD-ra, mivel a fiziológiás öregedés során is képződnek és rakódnak le fehérjék diffúz eloszlásban vagy plakkok formájában $[9,18]$. A szenilis plakkok mennyisége és elhelyezkedése nem korrelál a tünetek sú- lyosságával és a betegség időtartamával. Ezzel ellentétben a neurofibrillaris kötegek lokalizációja összefüggésben áll mind a tünetekkel, mind a betegség progressziójával [32]. Számos radiofarmakont fejlesztettek a fehérje minél pontosabb és érzékenyebb kimutatására, és a munkálatok jelenleg is folynak.

A PET-diagnosztikában a ${ }^{18} \mathrm{~F}$-izotóppal történő jelölés segíti a széles körú felhasználást, tekintettel az izotóp megfelelően hosszú felezési idejére, ami lehetőséget biztosít a ciklotronnal nem rendelkező PET-egységek ellátására is, mint ahogy az az FDG esetén is történik [22, 23]. A ${ }^{11}$ C-izotóppal történő jelölések a jobb jel/zaj viszony mellett előnyösek a gyógyszerkutatás egynapos, gyors vizsgálataiban is [46]. A jelenlegi és a még fejlesztés alatt álló radiofarmakonok fontos szerepet töltenek be nemcsak a diagnosztikában, hanem a kutatás területén is.

\section{Következtetések}

A dementia előfordulásának növekedése egyre nagyobb problémát jelent, különösen az elöregedő társadalmi struktúrával rendelkező országokban. A betegség leggyakoribb oka az AD, amely két jellegzetes kórszövettani eltéréssel társul: a $\beta$-amiloid alkotta szenilis plakkok és a tau fehérjéből felépülő neurofibrillaris kötegek. E két fehérje jelenléte lehetőséget nyújt arra, hogy a betegséget ne csak a strukturális elváltozások, valamint a metabolikus változások kimutatása alapján közelítsük meg, hanem a kóros fehérjék kimutatásával a háttérben álló patológia is jobban feltárható. A kórfolyamat minél közelebbi tanulmányozása, megértése segítséget nyújthat a hatékony terápiás lehetőségek kidolgozásához. Szerepük tehát nemcsak a kutatásban, a korai diagnosztikában, hanem a terápia minél előbbi megkezdésében és ezáltal a prognózisban is kiemelendő.

Anyagi támogatás: A közlemény megírása, illetve a kapcsolódó kutatómunka anyagi támogatásban nem részesült.

Szerzôi munkamegosztás: A szerzők egyenlő mértékben vettek részt a kézirat elkészítésében, a cikk végleges változatát elolvasták és jóváhagyták.

Érdekeltségek: A szerzőknek nincsenek érdekeltségeik.

\section{Irodalom}

[1] Borbély K. Functional imaging examinations in dementia - Part 1. [Funkcionális képalkotó vizsgálatok dementiában - I. rész.] Agyérbetegségek 2001; 7: 11-19. [Hungarian]

[2] Alzheimer's Disease International. World Alzheimer Report 2016. Available from: https://www.alz.co.uk/research/worldreport-2016 [accessed: September 27, 2018].

[3] Kollack-Walker S, Liu CY, Fleisher AS. The role of neuroimaging in the assessment of the cognitively impaired elderly. Neurol Clin. 2017; 35: 231-262. 
[4] Borbély K. New challenges and new potentials in the management of patients in oncology: PET/MRI clinical applications. [Újdonságok és új lehetőségek az onkológiai betegek terápiás vezetésében: PET/MR klinikai alkalmazások.] Magy Onkol. 2015; 59: 10-16. [Hungarian]

[5] Bouwman FH, Schoonenboom SN, van der Flier WM, et al. CSF biomarkers and medial temporal lobe atrophy predict dementia in mild cognitive impairment. Neurobiol Aging 2007; 28: 1070 1074.

[6] Borbély K. Clinical aspects of PET examinations. [A PET-vizsgálatok klinikai aspektusai.] Ideggyogy Szle 1998; 51: 274-280. [Hungarian]

[7] Borbély K, Kásler M. PET/CT and PET/MRI in oncology: diagnosis and follow-up of treatment efficacy. [PET/CT és PET/ MR képalkotás a daganatos betegek diagnózisában és a terápia eredményességének követésében.] Háziorv Továbbk Szle. 2018; 23: 504-507. [Hungarian]

[8] Borbély K. New challenges and perspectives in nuclear medicine imaging. [Újdonságok és új lehetőségek a nukleáris medicina képalkotásban.] Magy Onkol. 2014; 58: 232-238. [Hungarian]

[9] Borbély K. Visualisation of the brain dysfunction by functional imaging modalities. [Az agyi múködészavarok megjelenítése funkcionális képalkotó módszerekkel.] Medicina Könyvkiadó, Budapest, 2005; pp. 316-333. [Hungarian]

[10] Phelps ME, Huang SC, Hoffman EJ, et al. Tomographic measurement of local cerebral glucose metabolic rate in humans with (F-18)2-fluoro-2-deoxy-D-glucose: validation of method. Ann Neurol. 1979; 6: 371-388.

[11] Meles SK, Pagani M, Arnaldi D, et al. The Alzheimer's disease metabolic brain pattern in mild cognitive impairment. J Cereb Blood Flow Metab. 2017; 37: 3643-3648.

[12] Bao W, Jia H, Finnema S, et al. PET imaging for early detection of Alzheimer's disease: from pathologic to physiologic biomarkers. PET Clin. 2017; 12: 329-350.

[13] Scheltens NM, van der Weijden K, Adriaanse SM, et al. Hypometabolism of the posterior cingulate cortex is not restricted to Alzheimer's disease. Neuroimage Clin. 2018; 19: 625-632.

[14] Chiaravalloti A, Koch G, Toniolo S, et al. Comparison between early-onset and late-onset Alzheimer's disease patients with amnestic presentation: CSF and ${ }^{18}$ F-FDG PET study. Dement Geriatr Cogn Dis Extra 2016; 6: 108-119.

[15] Vanhoutte M, Semah F, Rollin Sillaire A, et al. ${ }^{18}$ F-FDG PET hypometabolism patterns reflect clinical heterogeneity in sporadic forms of early-onset Alzheimer's disease. Neurobiol Aging 2017; 59: 184-196.

[16] Kaether C, Haass C, Steiner H. Assembly, trafficking and function of $\gamma$-secretase. Neurodegener Dis. 2006; 3: 275-283.

[17] Hardy J, Allsop D. Amyloid deposition as the central event in the aetiology of Alzheimer's disease. Trends Pharmacol Sci. 1991; 12: $383-388$.

[18] Selkoe DJ. Biochemistry and molecular biology of amyloid $\beta$-protein and the mechanism of Alzheimer's disease. Handb Clin Neurol. 2008; 89: 245-260.

[19] Selkoe DJ, Hardy J. The amyloid hypothesis of Alzheimer's disease at 25 years. EMBO Mol Med. 2016; 8: 595-608.

[20] Klunk WE, Engler H, Nordberg A, et al. Imaging brain amyloid in Alzheimer's disease with Pittsburgh compound-B. Ann Neurol. 2004; 55: 306-319.

[21] Ng S, Villemagne VL, Berlangieri S, et al. Visual assessment versus quantitative assessment of ${ }^{11} \mathrm{C}$-PIB PET and ${ }^{18} \mathrm{~F}$-FDG PET for detection of Alzheimer's disease. J Nucl Med. 2007; 48: $547-552$.

[22] Rowe CC, Ackerman U, Browne W, et al. Imaging of amyloid $\beta$ in Alzheimer's disease with ${ }^{18} \mathrm{~F}-\mathrm{BAY} 94-9172$, a novel PET tracer: proof of mechanism. Lancet Neurol. 2008; 7: 129-135.
[23] Villemagne VL, Mulligan RS, Pejoska S, et al. Comparison of ${ }^{11} \mathrm{C}$-PiB and ${ }^{18} \mathrm{~F}$-florbetaben for $\mathrm{A} \beta$ imaging in agei ng and $\mathrm{Alz}-$ heimer's disease. Eur J Nucl Med Mol Imaging 2012; 39: 983989.

[24] Rowe CC, Pejoska S, Mulligan RS, et al. Head-to-head comparison of ${ }^{11} \mathrm{C}-\mathrm{PiB}$ and ${ }^{18} \mathrm{~F}-\mathrm{AZD} 4694$ (NAV4694) for $\beta$-amyloid imaging in aging and dementia. J Nucl Med. 2013; 54: 880-886.

[25] Higashi T, Nishii R, Kagawa S, et al. ${ }^{18}$ F-FPYBF-2, a new F18-labelled amyloid imaging PET tracer: first experience in 61 volunteers and 55 patients with dementia. Ann Nucl Med. 2018; 32: 206-216.

[26] Clark CM, Schneider JA, Bedell BJ, et al. Use of florbetapir-PET for imaging B-amyloid pathology. JAMA 2011; 305: 275-283.

[27] Landau SM, Breault C, Joshi AD, et al. Amyloid- $\beta$ imaging with Pittsburgh compound $\mathrm{B}$ and florbetapir: comparing radiotracers and quantification methods. J Nucl Med. 2013; 54: 70-77.

[28] Anand K, Sabbagh M. Amyloid imaging: poised for integration into medical practice. Neurotherapeutics 2017; 14: 54-61.

[29] Kudo Y, Okamura N, Furumoto S, et al. 2-(2-[2-dimethylaminothiazol-5-yl] ethenyl)-6-(2-[fluoro] ethoxy)benzoxazole: a novel PET agent for in vivo detection of dense amyloid plaques in Alzheimer's disease patients. J Nucl Med. 2007; 48: 553-561.

[30] Furumoto S, Okamura N, Furukawa K, et al. A ${ }^{18}$ F-labeled BF227 derivative as a potential radioligand for imaging dense amyloid plaques by positron emission tomography. Mol Imaging Biol. 2013; 15: 497-506.

[31] Nishii R, Higashi T, Kagawa S, et al. ${ }^{18}$ F-FPYBF-2, a new F-18 labelled amyloid imaging PET tracer: biodistribution and radiation dosimetry assessment of first-in-man ${ }^{18} \mathrm{~F}-\mathrm{FPYBF}-2$ PET imaging. Ann Nucl Med. 2018; 32: 256-263.

[32] Devous MD Sr, Joshi AD, Navitsky M, et al. Test-retest reproducibility for the tau PET imaging agent flortaucipir F 18. J Nucl Med. 2018; 59: 937-943.

[33] Gao YL, Wang N, Sun FR, et al. Tau in neurodegenerative disease. Ann Transl Med. 2018; 6: 175.

[34] Xia CF, Arteaga J, Chen G, et al. $\left[{ }^{18} \mathrm{~F}\right] \mathrm{T} 807$, a novel tau positron emission tomography imaging agent for Alzheimer's disease. Alzheimers Dement. 2013; 9: 666-676.

[35] Johnson KA, Schultz A, Betensky RA, et al. Tau positron emission tomographic imaging in aging and early Alzheimer disease. Ann Neurol. 2016; 79: 110-119.

[36] Bischof GN, Jessen F, Fliessbach K, et al. Impact of tau and amyloid burden on glucose metabolism in Alzheimer's disease. Ann Clin Transl Neurol. 2016; 3: 934-939.

[37] Whitwell JL, Graff-Radford J, Tosakulwong N, et al. Imaging correlations of tau, amyloid, metabolism, and atrophy in typical and atypical Alzheimer's disease. Alzheimers Dement. 2018; 14: 1005-1014.

[38] Mattsson N, Smith R, Strandberg O, et al. Comparing ${ }^{18} \mathrm{~F}-\mathrm{AV}$ 1451 with CSF t-tau and p-tau for diagnosis of Alzheimer disease. Neurology 2018; 90: e388-e395.

[39] Fodero-Tavoletti MT, Okamura N, Furumoto S, et al. ${ }^{18} \mathrm{~F}-$ THK523: a novel in vivo tau imaging ligand for Alzheimer's disease. Brain 2011; 134: 1089-1100.

[40] Okamura N, Furumoto S, Harada R, et al. Novel ${ }^{18} \mathrm{~F}$-labeled arylquinoline derivatives for noninvasive imaging of tau pathology in Alzheimer disease. J Nucl Med. 2013; 54: 1420-1427.

[41] Jonasson M, Wall A, Chiotis K, et al. Tracer kinetic analysis of (S) ${ }^{-18} \mathrm{~F}-\mathrm{THK} 5117$ as a PET tracer for assessing tau pathology. J Nucl Med. 2016; 57: 574-581.

[42] Chiotis K, Saint-Aubert L, Savitcheva I, et al. Imaging in-vivo tau pathology in Alzheimer's disease with THK5317 PET in a multimodal paradigm. Eur J Nucl Med Mol Imaging 2016; 43: 1686-1699. 
[43] Betthauser TJ, Lao PJ, Murali D, et al. In vivo comparison of tau radioligands ${ }^{18} \mathrm{~F}-\mathrm{THK}-5351$ and ${ }^{18} \mathrm{~F}-\mathrm{THK}-5317$. J Nucl Med. 2017; 58: 996-1002.

[44] Maruyama M, Shimada H, Suhara T, et al. Imaging of tau pathology in a tauopathy mouse model and in Alzheimer patients compared to normal controls. Neuron 2013; 79: 1094-1108.

[45] Betthauser TJ, Cody KA, Zammit MD, et al. In vivo characterization and quantification of neurofibrillary tau PET radioligand
${ }^{18} \mathrm{~F}-\mathrm{MK}-6240$ in humans from Alzheimer's disease dementia to young controls. J Nucl Med. 2019; 60: 93-99.

[46] Wang M, Gao M, Xu Z, et al. Synthesis of a PET tau tracer $\left[{ }^{11} \mathrm{C}\right]$ PBB3 for imaging of Alzheimer's disease. Bioorg Med Chem Lett. $2015 ; 25$ : 4587-4592.

(Borbély Katalin dr., Budapest, Ráth György utca 7-9., 1122 e-mail: dr.borbely.katalin@gmail.com)

\section{HELYREIGAZÍTÁS}

Angeli Orsolya dr. és munkatársai kérésére a Szerkesztőség megerősiti, hogy az Orvosi Hetilap 160. évfolyamának 29. számában az 1146-1152. oldalakon 2019. július 21-én megjelent „Szemfenéki arteria centralis retinae érelzáródás miatt kialakult hirtelen látásromlás spontán restitúciója cilioretinalis artéria jelenlétében" címü dolgozat Rövidítések jegyzékében a PCA = (posterior ciliary artery) arteria ciliaris posterior magyarázatban az angol ciliary szó helyett tévesen, nem a szerzők hibájából cerebral szó szerepel. 